Article

\title{
Refugees and Asylum Seekers Dispersed in Non-Metropolitan French Cities: Do Housing Opportunities Mean Housing Access?
}

\author{
Camille Gardesse * and Christine Lelévrier \\ Lab’Urba, University of Paris-Est Créteil, 94000 Créteil, France; E-Mails: gardesse@u-pec.fr (C.G.), lelevrier@u-pec.fr (C.L.) \\ * Corresponding author
}

Submitted: 15 February 2020 | Accepted: 6 May 2020 | Published: 28 July 2020

\begin{abstract}
Since 2015, policies for resettling asylum seekers and refugees in European cities have renewed the debate over the governance of migration, while not only metropolises but also small towns and mid-sized cities emerge as, although not new, at least specific arrival spaces. National dispersion policies are assigning these asylum seekers and refugees to small and mid-sized cities that are presumed to provide housing opportunities. However, little is known about access to housing and residential trajectories in these specific urban and socio-economic contexts. This article analyses how the housing providers-either state agencies, managers of temporary accommodation centres or social housing organisations-are adjusting to the arrival and needs of asylum seekers and refugees in cities where there is usually less ethnic diversity. We demonstrate that access to housing and residential trajectories tends to be determined by dispersion and mainstream social mix policies, from national to local arrangements. However, we argue that some pragmatic local practices have reframed this pattern to provide housing solutions that may be contrary to national policies. Our article will be based on 84 in-depth interviews conducted with housing providers, NGOs and with asylum seekers and refugees in three small and mid-sized French cities.
\end{abstract}

\section{Keywords}

asylum seekers; housing access; local planning; mid-sized cities; policies of dispersion; refugees; small cities; social and ethnic mix

\section{Issue}

This article is part of the issue "Urban Arrival Spaces: Social Co-Existence in Times of Changing Mobilities and Local Diversity" edited by Yvonne Franz (University of Vienna, Austria) and Heike Hanhörster (ILS-Research Institute for Regional and Urban Development, Germany).

(C) 2020 by the authors; licensee Cogitatio (Lisbon, Portugal). This article is licensed under a Creative Commons Attribution 4.0 International License (CC BY).

\section{Introduction}

Urban and migration research has mainly focused on global cities and metropolitan areas as places of arrival (Saunders, 2011) that are affected by an increasing 'super-diversity' (Vertovec, 2007), and as 'pragmatic' actors playing an increasing role in the multi-level governance of migration and diversity (Arino et al., 2018; Babels, Bontemps, Makaremi, \& Mazouz, 2018; Caponio, 2018; Dekker \& van Kempen, 2004). Since 2015, the policies to resettle refugees and asylum seekers in European cities have raised in different ways the issue of migration governance. European and national policies indeed dis- perse refugees and asylum seekers in order to avoid concentration spots in large cities or border areas. Small and mid-size cities are thus perceived as places of housing opportunities due to vacancies in less supply-constrained housing markets. However, little is known about access to housing and residential trajectories in these specific contexts. Recent research calling for a 'rescaling' approach in migration studies defines medium-sized cities as low- and down-scale cities. They may not provide as many opportunities for migrants in terms of employment, education and ethnic networks and they may lack public resources and experience of migration governance (Glick Schiller \& Çağlar, 2009). In this framework, 
not much research has been conducted into housing access except through national arrangements for reception policies and the selection process organized by the institutional state actors (Rigoni, 2018).

The aim of our article is to fill in this gap in research into small and mid-size cities as places and pragmatic actors by focusing on housing access through a multi-level governance approach. Beyond this national representation of small and mid-size cities as places of housing opportunities, how are reception structures for refugees and asylum seekers and for those whose requests have been rejected actually provided in these local contexts?

Using 84 in-depth interviews conducted in three French cities, our article focuses on the narratives and set of actions put forward by diverse housing providers and the arrangements that are driving housing access. The article analyses how the housing providers-either state agencies, managers of temporary accommodation centres or social housing organisations-are adjusting to the arrival and needs of asylum seekers and refugees in cities where there is usually less ethnic diversity. We assume that crossing analysis relating to housing and migration policies and practices, on the one hand, and the residential experiences of these exiles, on the other hand, could give new insights into issues of migration governance. The exiles we are talking about are those affected by public reception arrangements for asylum seekers: Some are subject to the Dublin Regulation (they are referred to as 'Dublinised') and must return to the first European country in which they were registered; others will have their applications rejected and still others (a minority) will obtain refugee status.

First, we will look at previous research findings concerning migration governance and housing access in different types of cities. Next, we demonstrate how access to housing and residential trajectories is determined by dispersion and social-mix mainstream policies from national to local arrangements. However, we argue that pragmatic actors may adjust their discourse and day-today practices to provide housing solutions, just as residents may rise up in support of the most vulnerable.

\section{Migration Governance and Housing Access: Previous Research}

Some comparative research into the governance of diversity highlights 'the growing dissonance' between the prevalent 'assimilationist' rhetoric of national governments and the more 'tolerant' approach of cities in Europe (Arino et al., 2018; Raco, 2018). Cities act as "strategic players" (Dekker \& van Kempen, 2004), capable of reshaping or even challenging national narratives and setting up divergent specific local arrangements (Arino et al., 2018; Escafré-Dublet \& Lelévrier, 2019). Recent research analysing European city networks shows how cities seize this opportunity both as a way to politically oppose national or European discourse and strategies, and to find pragmatic solutions to the in- flux and settlement of migrants (Bazurli, 2019; Caponio, 2018; Downing, 2015). Approaches to multi-level migration governance underline two strong trends: increasingly Europeanized supra-national policies (Guiraudon, 2010) and a more and more central role for local actors. The 'local turn' (Scholten \& Penninx, 2016) thus reflects the "prominent and entrepreneurial" role of cities "drawing up their own agenda, policy strategies and key questions/answers to the challenges related to integration and the accommodation of diversity" (Zapata-Barrero, Caponio, \& Scholten, 2017, p. 2). Certain municipalities even take over the management of domains in which they deem the State to be inefficient, creating forms of 'neo-municipalism' (Furri, 2017). This 'local turn' goes hand in hand with the emergence of new civil society stakeholders involved in taking in migrants. This is the case in Paris, where it was the inhabitants who made it a 'welcoming' city (Babels et al., 2018). On the one hand, such mobilization of civil society is a local adaptation to the austerity leading to a devolution of responsabilities. On the other hand, it reflects forms of creeping decentralization, even though cities have few legislative possibilities for influencing migration policies (Pauvros, 2014). Given the diversity in cities' positions and capacity for action, these localist policies risk reinforcing the segregative effects and inequality of asylum seeker and refugee reception facilities based on the resources and willingness of local authorities.

Two recent ANR-sponsored (French National Research Agency) projects highlight some findings on diverse French cities. The ANR project Babels provides an insight into the inter-dependent relationships between migrants and cities and the forms of hospitality (or rejection) set up for 'migrants' in Europe and France. The three types of city studied-crossroads cities, refuge cities and border cities-are nevertheless mainly large cities such as Berlin, Paris and Istanbul, or specific border cities like Calais and Lampedusa (Babels et al., 2018). Moreover, although some residential trajectories leading asylum seekers and refugees from Paris to mid-sized cities have emerged (Deschamps, Laé, Overney, \& Proth, 2017; Lae, 2018), housing and housing providers have not been explored extensively. The ANR project CAMIGRI is analyzing the 'reception policies,' with one axis focused on 'residential spaces' of migrants in French cities. However, the research objective is to use international migration to shed light on the changing dynamics of rural areas (Berthomière \& Imbert, 2019). Moreover, lots of research in this area is focusing either on the political discourse and arrangements of mayors and city departments or on the initiatives deployed by local actors (Béal \& Pinson, 2014), social workers and citizens and the theory of social movements (Bazurli, 2019; Gebhardt, 2016; Rigoni, 2018). Not as much is known about other local housing providers.

Some research is nevertheless emerging on the governance of migration in small and mid-sized cities notably after 2015 (Glick Schiller \& Çağlar, 2009; Meier, 2018; Raüchle \& Schmiz, 2019). The most common European 
statistical threshold used for mid-sized cities is a population of between 20,000 and 100,000 inhabitants as the definition of small towns appears to be uncertain. Most urban research converges around the idea that the definition of small towns and mid-sized cities is related more to their intermediary status and functions between rural areas and large cities than to any threshold. Urban research is increasingly highlighting the diversity of small and mid-sized cities as some of them are experiencing demographic and economic growth rather than decline and their relevance to understanding the complexity of cities (Bell \& Jayne, 2009).

The rescaling approach in migration studies also defines small and mid-sized cities in terms of their position within the global and national hierarchy on a relational continuum from top- and up-scale (metropolitan) to low- and down-scale (small and medium-sized; see Glick Schiller \& Çağlar, 2009). One of the benefits of this approach is to conduct a cross-analysis of contexts and actors, including the refugees and asylum seekers themselves, and to outline the differences in opportunities for migrants according to the types of cities. The assumption is one of less opportunities in terms of ethnic resources, education and unemployment for migrants in small and mid-sized cities. This could nevertheless be questioned regarding housing. To be more specific, there is a need to qualify the types and the location of housing provided in these small and mid-size cities where the share of social housing may be under the national average. Within the framework of the rescaling approach, recent research into migrant economics in two mediumsize German cities explores the 'opportunity structures,' "defined as consisting of technological developments, production factors, market conditions, demand, welfare systems and the legal frameworks" (Raüchle \& Schmiz, 2019 , p. 1769). Although 'opportunity structures' as a concept has been used to analyse the multi-level and embedded arrangements for the economic integration of migrants, housing market policies and neighbourhoods are part of this.

Housing provision and access is both a crucial resource for migrant integration and a relevant approach to looking at the multi-level governance issues involved in combining migration and housing policies. In France, research has outlined different key issues. First, the rate of social housing $(17 \%)$ has been one of the key vectors of housing provision for immigrants in the 1970s even if they have tended to end up in large poor social housing estates with a high concentration of migrants. As in other European countries, area-based policies address this concentration of poor and immigrant households in deprived neighbourhoods (Bolt, Phillips, \& van kempen, 2010). This model reflects a mainstream 'colour-blind' universalistic framework of "the philosophy of integration" based on individual immigrant incorporation into the French political community (EscafréDublet \& Lelévrier, 2018; Favell, 1998) which shapes governance arrangements (Arino et al., 2018) and leads to the mainstream social mix objective guiding allocation systems in 'ordinary' social housing and immigrant distribution in neighborhoods and cities (Blanc, 2010; Simon \& Sala-Pala, 2010). However, urban research has highlighted how the "institutional racism" and ethnic discrimination of street-level bureaucrats is driving unequal access to housing (Sala-Pala, 2013). In any case, access to standard social housing is contingent on legal status which may exclude some asylum seekers and refugees. As such, the newly arrived asylum seekers are especially vulnerable and poorly housed because they cannot benefit from different forms of solidarity from people who have already been allocated housing (Lévy-Vroelant, 2014). Moreover, the most vulnerable migrants are often accommodated in 'constrained housing' structures (Bernardot, 2005), while urban hospitality facilities may be transformed into places of confinement or isolation, or even serve as holding centres prior to expulsion (Kobelinsky, 2008; Valluy, 2007). Housing opportunities are therefore reduced for asylum seekers, who are forced to stay in specific types of accommodation, while access to more standard-type housing is governed by a series of arrangements that are rooted in universalist French housing models, but give rise to discriminatory practices (Bourgeois, 2017).

The aim of this article is to fill the gap in research into migration governance post-2015 in contexts other than large cities-especially in France-and to provide insights into housing opportunities and access. In doing so, our main focus is the manner in which migration policies and housing policies and practices are combining to provide local housing opportunities, and to what extend the different housing managers and providers favor (or do not favor) housing access for asylum seekers and refugees. This approach could provide fresh insights into rescaling and multi-level governance approaches.

\section{Presentation of Research Sites and Methodology}

This article draws upon the findings of exploratory research conducted between June and October 2019 for which we selected three towns with different sociodemographic dynamics and urban issues : Saint-Liorac, in central France, Locheronde, in western France, and Layronastre in southern France. These names are pseudonyms because we elected to preserve their anonymity: that is why we are quite vague about their location. These three cities can be qualified as small and medium-sized not merely because of their populations, but also because of their role as urban centres within a radius of between 10 and 20 kilometres (Mainet, 2011), and because they are relatively far away from centres of power. In all cases, statistical data reveals migrant populations that are well below those of the Paris region (see Table 1). We chose to study three cities that differ in several respects to try to understand what is common to specific relocation experiences outside of metropolitan or border areas, and what factors may be considered 
Table 1. Socio-demographic data of sites researched.

\begin{tabular}{|c|c|c|c|c|c|}
\hline Cities & Population & $\%$ Migrants & $\begin{array}{l}\text { Annual } \Delta \text { in population } \\
\text { 2011-2016 }\end{array}$ & $\begin{array}{l}\text { Unemployment } \\
\text { rate }\end{array}$ & $\begin{array}{c}\text { \% Rented social } \\
\text { housing }\end{array}$ \\
\hline Saint-Liorac & 25,954 & 5 & -1 & 14.1 & 17 \\
\hline Locheronde & 53,741 & 6.4 & +0.4 & 17 & 22 \\
\hline Layronastre & 8,380 & 6 & +0.9 & 18.3 & 14 \\
\hline Paris & $2,190,327$ & 20.3 & -0.5 & 12.1 & 21.1 \\
\hline Paris Region & $12,117,131$ & 19.2 & +0.4 & 9.7 & 25 \\
\hline
\end{tabular}

Source: From the national population census, 2016.

as specifically local ones : while Saint-Liorac has a declining population, Layronastre, with a much smaller population at the moment, is witnessing positive net migration, reflecting its strong residential attractiveness. However, these three cities have all recently been confronted by an increase in arrivals of refugees and asylum seekers, in ways ranging from the opening of public reception facilities to strong citizen activism.

Our research compares and contrasts national reception policies for asylum seekers and refugees, with the local practices of accommodation providers involved both in managing specific types of housing and in access to standard housing. The qualitative methodology developed in the research was based firstly on the study of local documents relating to the organisation and management of access to accommodation and housing and, secondly, on 84 semi-structured interviews (with 134 interviewees), including 29 with refugees, asylum seekers and 'Dublinised' (48 interviewees; see Table 2). We questioned them about their residential trajectory since they emigrated and their urban experiences. The other interviews allowed us to analyse the discourse and practices of all of the actors involved: local representatives of central government, local authorities, providers of social housing, managers of accommodation facilities, residents' associations and residents who are providing accommodation.

\section{A National Dispersion-Based Approach: Institutional Reception Channels}

Analysing how accommodation and housing is managed for refugees and asylum seekers shows how the state plays a predominant role in the spatial allocation of peo- ple and, ultimately, in relocating them to small and midsized cities. The programmes driven by the central level of public action are framed by national migration policy, which is based upon migrant categorization and sorting arrangements.

\subsection{Accommodation Facilities and Administrative Categories That Influence Residential Situations}

The channels for accessing specific accommodation facilities in small and mid-sized cities are structured by the Dispositif National d'Accueil (National Asylum Programme, or DNA), through which the government provides asylum seekers and refugees who have neither resources nor housing with administrative support and accommodation. Since it was set up in 1973, reception facilities have constituted a category of public action. The term 'migrant,' frequently used since 2015 to denote different DNA missions and programmes, cuts across several administrative and legal situations, ranging from 'asylum seeker' to 'refugee' (about $27 \%$ of asylum seekers in France), 'rejected applicants' or 'Dublinised.'

To simplify matters, we propose to divide the complex institutional channels into three broad categories: 1) so-called temporary reception facilities, which provide access to cohabitation facilities or individual accommodation for several months, pending the examination of the asylum application; 2) access to standard permanent housing for people who have been granted refugee status entitling them to stay in France on a long-term basis, and which is intended to help them access their basic rights; and 3) emergency accommodation, which in theory provides people with insecure or illegal administrative status with shelter for one or several nights.

Table 2. Types of actors who participated in the 84 semi-structured interviews.

\begin{tabular}{lcccc}
\hline Number of interviewees/city & Layronastre & Saint Liorac & Locheronde & TOTAL \\
\hline State agencies and representatives & 3 & 1 & 4 & $8(12)$ \\
Local authorities (cities and departements) & 1 & 1 & 3 & $5(8)$ \\
Social housing organisations & 1 & 2 & 3 & $6(6)$ \\
Managers of accommodation facilities & 6 & 4 & 7 & $17(21)$ \\
Resident support groups (either organised as NGOs or not) & 12 & 3 & 4 & $19(39)$ \\
Asylum seekers and refugees & 12 & 9 & 8 & $29(48)$ \\
Total & $35(46)$ & $20(44)$ & $29(44)$ & $84(134)$ \\
\hline
\end{tabular}


The diagram below (see Figure 1) demonstrates the link between administrative categories and residential circumstances: An asylum seeker is supposed to be accommodated in a reception facility (blue) and then, depending on whether or not they obtain refugee status, they will be either channelled into permanent accommodation (green) or have to resort to emergency accommodation if they are rejected or 'Dublinised' (red). Our research shows that, in reality, this trajectory is often much less linear, in particular due to the saturation of many facilities. For example, asylum seekers frequently begin in emergency accommodation before they are able to access reception facilities, just as it is common for refugees to be stranded in temporary facilities for asylum seekers.

\subsection{Geographical Dispersion Policies Out of Large Cities and Border Towns}

Refugee and asylum seeker dispersion-based approaches are common to all programmes aimed primarily at organising national spatial distribution outside of the hotspots, i.e., mainly Paris and its region on the one hand, and border towns on the other, especially Calais in the North of France, located on the English Channel with access to England, and Ventimiglia on the French-Italian border. Indeed, in 2015-2016, many people arriving in France in the hope of being granted asylum or wishing to travel through France to apply for asylum elsewhere, have become concentrated in these territories. Devoid of resources or support from the public authorities, they settled in large camps on the streets of Paris or, in Calais and Ventimiglia, on the outskirts in areas known as 'Jungles' (Babels et al., 2018).

Through its decentralised agencies, especially the Local Directorates for Social Cohesion and Protection of the Population (DDCSPP), the government has organised the geographical distribution in diverse reception Centres. The DDCSPP put out calls for tenders to find operators for this accommodation facilities and they rally local stakeholders, especially municipalities, to make sure they are on board. They also gather data on the number of available places to enable central government agencies to coordinate operations at national level via the Office Français de l'Immigration et de l'Intégration, the French agency in charge of immigration and integration.

We encounter the same approach in 'geographical mobility' and 'relocation'-type housing access programmes. Central government seeks to ensure that people who obtain refugee status in the Paris region opt to relocate to housing outside the Greater Paris area. This was the mindset behind the creation of a national refugee rehousing platform by the state which seeks to match the supply of vacant properties in small and midsized towns with officially recognised refugee applicants. Despite mixed results (only $10 \%$ of the targets of 2,000 and 1,000 relocations planned for 2018 and 2019 were achieved), central government continues to develop this programme by seeking to link it more closely to job offers. But in reality, out of 2,595 beneficiaries of international protection by December 2018, only 218 people (8.4\%) stated that they were willing to opt for a solution outside of the Paris region (GIP-HIS, 2018).

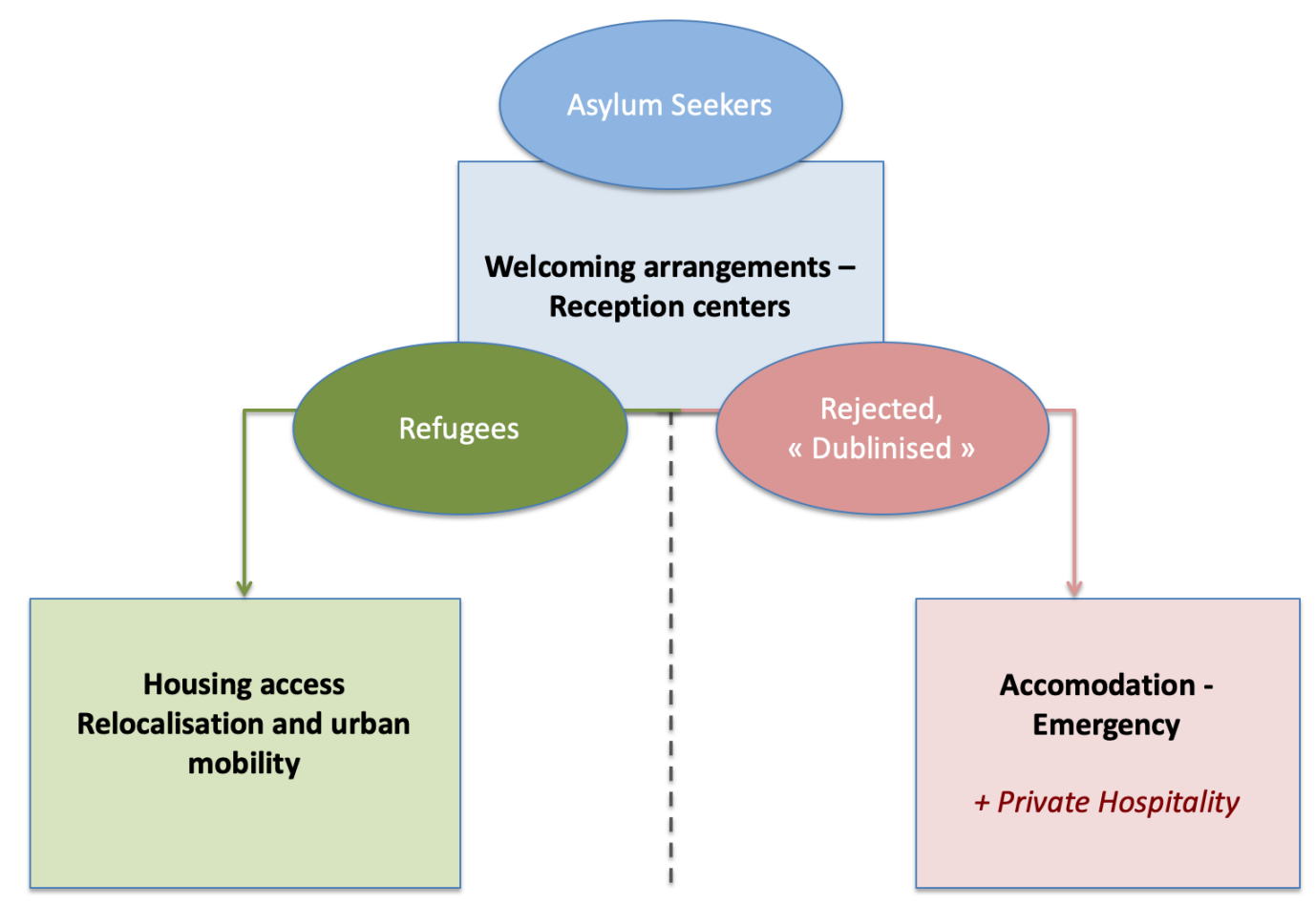

Figure 1. Formal trajectory of an exiled asylum seeker among the various facilities available based on their administrative status. Diagram based on our research fieldwork and DNA documentation. 
The three towns we have studied are part of the DNA but this top-down reception policy organised by the state is implemented at regional and departmental level. Our research shows that governance of these facilities is the responsibility not of the municipalities but of the government subcontractor agencies located in different towns within a département: In western France, there are four NGOs with space for 990 people, in central France three facilities accommodate 336 people and in southern France, five facilities can hold 659 people. Aside from this specific accommodation, exiled migrants can also be accommodated in ordinary housing or by individuals. As shown in the map of one of the 'cities,' specific accommodation is spread out between nine small local sites that are managed by the local representatives of the state at the level of the department.

\subsection{The Stamp of Imposed Trajectories: Settling in an Unknown Town}

Exile people we interviewed who have been living in cities for several months or years are generally positive about the location. However, the experience of having a residential trajectory imposed upon them in an unknown city, far from any social ties or cognitive reference points, continues to be perceived negatively. Several respondents emphasised that they did not have any choice in this location, highlighting the implied stress of this. Let us take two typical examples that reflect strong patterns identified in the trajectories studied. At the end of 2014, Mikayla, Bodan and their two children arrived from Ukraine in Strasbourg, where Bodan's sister and family live. The government puts them up in a filthy ho- tel, where they are eaten alive by bedbugs and they wish to apply for asylum. This is when they realised that to get support and access to decent housing, they had to agree to leave Strasbourg and go several hundred kilometres away, to a small or mid-sized town they have never heard of. They would have preferred to stay close to their family network, but they agree to move to this town because it was the only way of securing their basic rights:

Well, you're entitled to refuse, but then you don't get any support. That's the way it is. All the doors are closed if you refuse. And because we don't speak French or know anything about French law, we can't live here without help. That's why we came. But it's stressful in the beginning because we lived in Strasbourg for two months and because we didn't speak French, we lived with my husband's sister. It's normal for us to live together. It's good for communication. (Mikayla, Saint-Liorac)

Sadri, a 32-year-old Afghan man arrived in France on his own. He immediately travelled to Calais because he wanted to get to England. He speaks English. There were a few dangerous and unsuccessful attempts to get there and he was still in the Calais Jungle when it was broken up in October 2016. The alternative proposed by the French government was as follows : Either he applies for asylum, and this involves getting on a bus that will take him to a reception centre in some faraway part of France, or he declines to do so and remains in an irregular situation at risk of permanent expulsion (Le Courant, 2016). He decided to get on a bus without knowing where he was going:

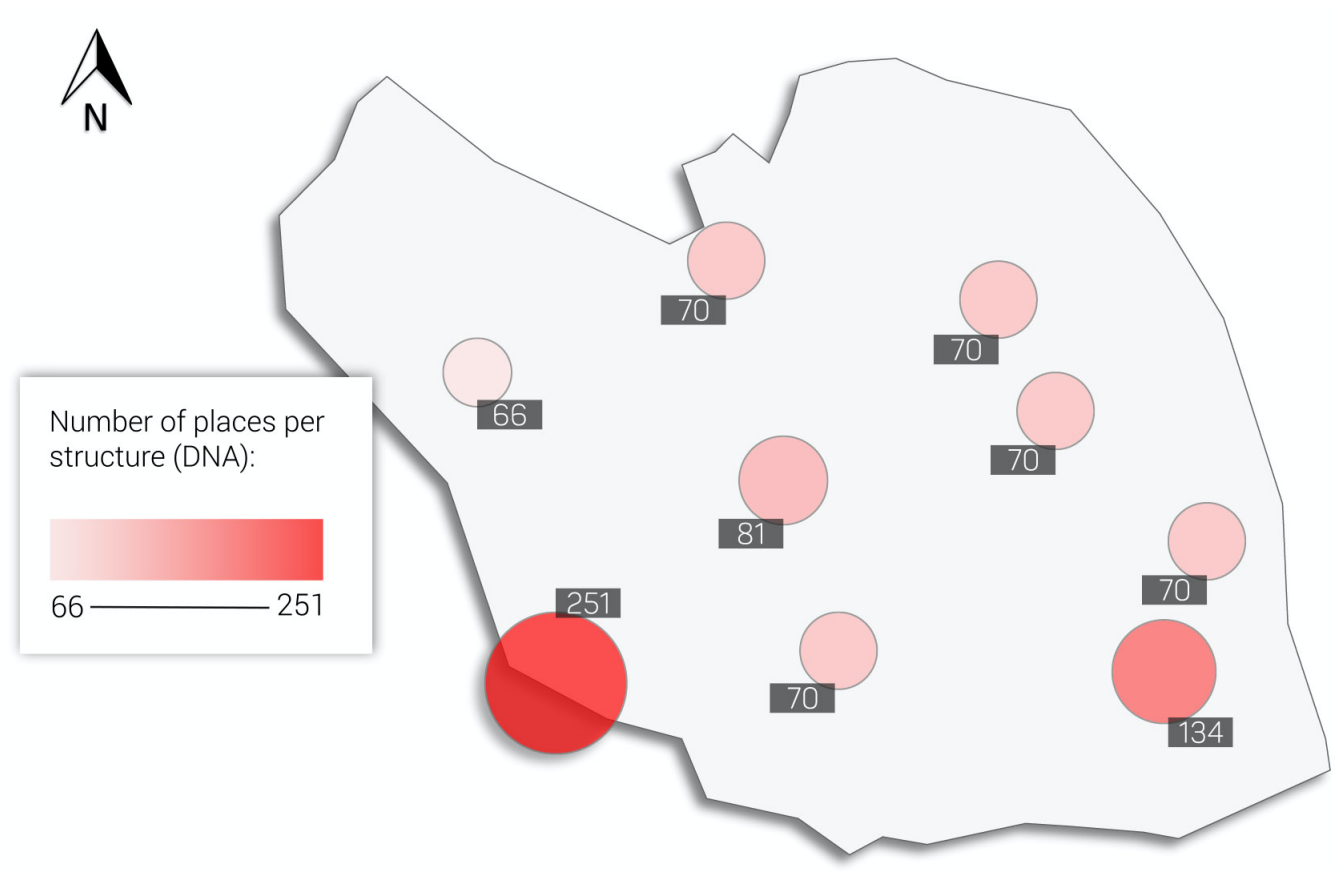

Figure 2. Schematic dispersion of DNA applicants at departmental level of the western city: Number of places per structure. Schematic map based on fieldwork and designed by Jules Jung (Blitzz studio). 
At a certain stage I requested asylum. I said I would go. After that there were buses and people transferring refugees. I didn't realise and my friend said: 'Ask where we're going? To what place? Look on a map to see if it's a city or not!' But I said, 'let's just go!' We didn't have any choice. (Sadri, Layronastre)

There are many stories just like Sadri's, of people who did not know their final destination, describing people crying on arrival and sometimes even refusing to get off the bus. The arrivals are often experienced as an ordeal, just like all of the to-ing and fro-ing and the length and complexity of the administrative procedures.

\section{When Social Mix Becomes Ethnically-Based and Adjusts to the Housing Supply}

National references (to assimilation and mix) permeate the discourse of the housing providers interviewed. The ethnic categorizations they use to select housing applicants influence trajectories, even though they adjust their practices to the housing stock in the cities studied.

\subsection{Mix and Dispersion: From Assimilation to Ethnic Categorization}

In our three research sites housing providers are mainly the shelter managers, the main not-for-profit social housing organisations, local representatives of central government agencies and the municipalities. Despite the specific social and residential features of these local contexts, social mix is a central and recurring term in their discourse. The overriding imperative of social housing organisations is, according to the interviewees, to "avoid concentrating" asylum seekers and refugees, but this is embedded in a generalised discourse about 'migrants,' this category including for the interviewees, all people with a migrant background. The first argument in favour of this policy refers to the fact that migrants are deemed to be 'poor.' Mix is considered a question of "balancing the population" "at local and regional level." Allocation strategies therefore factor in not just housing availability but the concentration of poor and migrant people. This concentration is presented by social housing organisation in Locheronde as posing a risk of aggravating management difficulties, of "bad debts" and "stigmatization." In two of the sites studied, this discourse is associated with large housing estates considered to be 'ghettos.' Allocating such housing to refugees would thus run counter to the idea of mixing up different profiles for the purpose of attracting the middle classes to the newly renovated housing:

At a certain point, there has to be a mix and this mix depends on a settlement policy, because we have a very vulnerable and a foreign population. In other words, that means bringing housing products, and people...who are a little wealthier than the existing population. (Social housing organisation, Saint Liorac)

The idea that migrant people should be dispersed within the city ties back to a second line of argument whereby living in an ethnically diverse environment facilitates social 'integration.' An interviewee from a social housing organization (Saint Liorac) reported that concentration would only result in "conflict" and risks of "communities turning in on themselves." In practice, it's not just about not putting all "migrants" in the same place; it is also about not putting all people of the same origin together in a particular part of the city, in the same stairwell or in a shared apartment. Interviewees pointed out that the dispersal of "compatriots" into various shared accommodation structures, as advocated by associations, avoids "ghettoization" and encourages "language learning," the adoption of "good living practices" and a willingness to "live together":

Mix really is the best thing. It's better to mix people of different nationalities. There will be respect due to the fact that they don't know each other, whereas if you put Georgians and Syrians together, they will be familiar with the same codes so they will be more demanding of each other. (Social worker from an accommodation centre, Layronastre)

Within this mindset, discourse is punctuated by ethnic categorizations. Accommodation providers distinguish between 'migrants' and other residents. They also construct ethnic groups based on (real or assumed) religious and cultural differences by classifying them according to their supposed ability (or inability) to integrate or get along with other groups:

Take Chechens and Armenians for example. Armenians integrate much more easily and are much more social. They open businesses and so on. Chechens are very different. (Social housing manager, Saint Liorac)

Access to specific housing as well as to standard housing is conditioned by this dispersion-based approach to mix. These ethnic categorizations both tend to reduce the potential supply of housing and thwart the affinities and aspirations of people who want (or don't want) to live together. They result in random and unequal access to housing. For example, a social housing provider justifies their refusal to allocate housing to Syrian refugees on the grounds that there are too many Syrians in a certain neighbourhood.

\subsection{From Housing Opportunity to an Unsuitable Offering}

Four findings emerging from the research conducted questions the opportunity of housing in these cities. First, 
housing vacancies, which vary between the three sites, have fallen since 2015. Next, the issue is more bound up with location, type of housing, and rents for available housing. Indeed, at all three sites, supply is not adapted to the demand for housing as a whole, and even less so for refugees and asylum seekers; the dominant type of housing comprises individual privately-owned standalone housing; the share of collective social housing is lower than in the big cities and is concentrated in a few neighbourhoods in the city centre area; the rest of the supply is much more heterogeneous and consists mostly of large detached houses scattered throughout smaller municipalities. Most available dwellings are three-andmore-room units, whereas demand is for smaller oneand-two-room units. As regards new housing, including new social housing built with loans targeting lowincome households, high rents make it inaccessible to the least well-off.

In fact, access to housing for refugees and asylum seekers is not managed at municipal level but in line with the housing portfolios of landlords and departments. This supply-demand mismatch impacts not just access to housing for refugees and asylum seekers but their living conditions and day-to-day mobility. When they accept this housing, these people are confronted with both isolation and difficulties in accessing jobs, often located on the (industrial) periphery of cities or the (agricultural) outskirts of towns. Their poor mobility is linked as much to the lack of regular urban transport as to the fact that they do not have a car or a valid French driving licence. Consequently, the dispersion strategy conflicts with the stated national imperative of integrating refugees.

\section{Local Adjustments and Initiatives in Housing Access}

All of the institutional stakeholders in charge of refugee and asylum seeker accommodation and housing are caught up in conflicting imperatives that may stem from their own professional trajectories, positions and ethics or due to the reception and housing policies (Frigoli, 2004; Rigoni, 2018). These paradoxes result in pragmatic readjustments and tinkering to facilitate action and handle local situations.

\subsection{Tinkering with the Republican Model: Priority in Access to Housing}

As regards basic rights to social housing, refugee and asylum seeker requests are in principle, treated in the same way as other requests. However, in two of the cities, local housing providers actually strayed away from this principle of equality. Priority treatment of refugee housing requests was mainly justified by the need to "relieve bottleknecks" and "free up spaces" in specific accommodation facilities, which would be saturated by people who had obtained refugee status without having any housing solutions. Rather than the argument of integration, accommodation providers talk about pragmatic management of the local effects of asylum policies.

In one of the cities, this treatment is simply to bolster refugee housing applications. In the other, a quarterly local commission bringing together social housing organisations, state agencies and managers of reception facilities has been set up specifically for this purpose. It examines refugee applications and points them towards available social housing. Thirty refugees were rehoused in one year using this process. Local stakeholders are caught between two contradictory requirements: the urgency of rehousing refugees to free up places for asylum seekers, and the objective of social mix which would lead to not rehousing people in places where there is adequate supply.

Therefore, local management of refugee and asylum seeker residential mobility leads to two types of pragmatic readjustments vis-à-vis the official discourse on social mix. On the one hand, local actors practise a form of positive discrimination that deviates from ordinary law, although they are not able to frame it in these exact terms due to French 'colour-blind' and equality principles. Some players referred to this arrangement as a 'refugee contingency,' but others refused to call it that. On the other hand, the need to rehouse people has resulted-at least in one of the cities-in a preference for neighbourhoods deemed to be places of concentration, i.e., in areas which are the focus of urban policy, unlike social mix.

\subsection{The Informal Practices of Social Workers to Keep the Most Vulnerable Off the Streets}

Local readjustments are largely based on individual initiatives by social workers. While some-especially the managers of specific structures-proffer a 'legalistic' discourse emphasising compliance with governmental standards, others develop practices that bend the rules. This generally involves social workers working directly with exiles. To bring administrative status more firmly into line with family situation, trajectory or aspirations, social workers frequently decide, in an informal and sometimes hidden manner, to derogate from certain rules.

For example, if residents of a temporary reception centre for asylum seekers who have been granted refugee status refuse to accept accommodation offered to them, they can be turned out on the street. Justification for such refusals must be based on strict criteria which are not always very clear or adapted to refugee situations. To avoid turning people onto the streets, a social worker at Layronastre says she "masks" their refusals. She uses the false argument of a mismatch between the refugee family profile and the housing that they are being offered.

Social services also have to deal with the demands and needs of people whose asylum requests have been rejected or who are 'Dublinised.' The Prefecture acts as if these people have been deported while they are still ac- 
tually living in the city. To find solutions for families who are sleeping in the streets and suffering from hunger, one local council (Locheronde) has adjusted the legal conditions regarding social aid granted to individuals "whose papers are in order" so that it can include such people in the 'grey area' of reception policies, "people who were already here but whose applications have been rejected, or who sometimes arrive in an irregular situation. It is also common for social workers who have no solution to offer migrants who lose their right to accommodation, to take it upon themselves to contact networks of citizens who take people into their own homes in order to find some sort of a solution.

\subsection{Private Hospitality: When the Residents Get Involved}

Non-institutional accommodation-organised by, and in the homes of residents-has developed systematically, with more intensity in Layronastre where public authorities are less involved. Those whose asylum applications have been rejected or 'Dublinised' are most at risk of homelessness and these are the people usually cared for by residents. In Saint-Liorac, decentralized government agencies have even told the Emergency Shelter Centre operators not to accept unsuccessful applicants onto the programme. This decision was taken after it was noted that $100 \%$ of available places were actually occupied by them, which was deemed by public authorities to represent an 'embolization' of emergency accommodation by such people. Obviously, those people have not disappeared from the city, they are simply wandering around. Even though the same facilities operator has been able to create an ad hoc structure to receive them, it has four times fewer places than the original centre. So, this specific bending of the rules tends to work against migrants, specifically 'Dublinised' and rejected people. In this context, a network of accommodation providers is gradually being set up, notably to provide shelter for people who can no longer apply for local emergency accommodation.

In Layronastre, solidarity-based accommodation has been extensively developed over the past few years: it enables people who have to leave reception centre as well as other categories such as unaccompanied minors not taken into care by the state to be housed for a few months or even years. Arrangements can range from cohabitation in a shared flat to a room provided in a family home. Often, while the gateway to this solidarity is via access to shelter, the activism of residents of the cities helps make up for the shortfall in care provided by the public authorities. For example, commissions dealing specifically with transport issues are often set up: In the case in point, residents offer rides in private cars to do the shopping, or they accompany people to meetings with the administration which are often in large cities hundreds of kilometres away.

\section{Conclusion}

The main outcome of our empirical study is to demonstrate how asylum seeker and refugee housing access in French small towns and mid-sized cities is driven by dispersion policies underpinned by two types of arrangements. On the one hand, specific housing for asylum seekers and refugees is provided through national $\mathrm{mi}-$ gration policies, especially within the framework of the DNA. Dispersion is underpinned by migrant flow management and control from the national to the local level. Next, our research reveals that the administrative system for asylum seekers and refugees is not set up for just one city but is managed at the departmental level where dispersed small arrangements are provided throughout the territory. Moreover, our research shows how access to these programmes is provided via administrative sorting categories that assign asylum seekers and refugees to different programmes based on their status. It demonstrates how these arrangements are focused first and foremost on managing the shortage of places or the length of stays with regard more to smoothing migrant flows than to integrating them. As such, those who are most vulnerable, i.e., 'Dublinised' and rejected applicants, are those most frequently turned out onto the street.

On the other hand, local housing solutions that include social housing are also set up in partnership with different housing providers. Here, housing access is driven by the strong social-mix focus in French housing policies (Blanc, 2010). Our research shows how social mix permeates official discourse to justify geographical distribution and ethnic sorting within neighbourhoods and cities. Social mix is used as an argument for 'more effective integration' of 'migrants,' echoing the French philosophy of integration (Favell, 1998) and not recognising intermediary groups between the national community and citizens (Escafré-Dublet \& Lelévrier, 2019). This social mix strategy may actually be easier to implement than in large cities as the housing supply is highly dispersed in 'bunches' of localities throughout the departmental territory. However, there is often a mismatch between this housing configuration and migrants' actual needs in terms of transportation and urban services. Therefore, local housing stakeholders often adjust this mix principle in order to accommodate people and this may include agreeing to allocate them to large public housing complexes that already have a large concentration of migrants.

Our research shows how these twofold dispersion strategies have direct consequences on the residential experiences of refugees and asylum seekers: they are encountered all along their residential trajectory, from allocation to an unknown city to their cohabitation arrangements and housing locations. Ethnic categorizations are strongly determining unequal and random residential assignments reflecting forms of "institutional racism" (Sala-Pala, 2013). Not only do they deny refugees and asylum seekers the resources that people usually 
draw upon in community groups, but they also prevent them from leveraging networks, especially when they arrive. Moreover, the stock of housing in the cities studied does not necessarily constitute a resource for refugees and asylum seekers as the supply of affordable housing adapted to their households is severely limited or poorly located.

Therefore, an analysis of asylum policies demonstrates the central role of the French state-at the national and the local level-in defining, deploying and coordinating these actions. Indeed, this top-down, hierarchical policy is coordinated locally by decentralised government services through specific accommodation and housing programmes delegated to a plethora of agencies with varying degrees of expertise in asylum-related issues. Moreover, the local representatives of the state are also central agents in local housing policies and practices, mobilizing the supply of local housing and organizing fast-tracking and partnerships for refugee access to social housing, at least in two of the studied cities.

However, these highly restrictive frameworks do not preclude informal or individual strategies of adjustment and circumvention that emerge from local interaction. In the three cities studied, civil society is becoming involved, especially in places where the local authoritiesrepresenting the state and the municipality-are not so pro-active, which is in line with the findings of other research (Babels et al., 2018). Residents mainly help people who have not been granted refugee status or those waiting to be taken into public reception facilities. Therefore, at local level, action is being polarised between, on the one hand, standardised institutional channels providing accommodation and support to asylum seekers or refugees and, on the other hand, more informal care structures for those who have no real status, often taken care of by local residents and municipalities.

Our research has therefore led us to refine the "local turn" concept (Zapata-Barrero et al., 2017) in the French context in which small and mid-sized municipalities are more reactive than proactive in providing access to housing, in constrast to larger cities. Our analysis of multi-level governance in housing provision and access tends to highlight the key role of intermediate actors such as the managers of shelters, social housing associations, civil society and the local representative of the state. Our research also calls for a redefinition of the political and geographical framework as well as the complex system of national and local arrangements in these small towns and mid-sized cities, thus providing some insights into the rescaling and opportunity structures approach (Glick Schiller \& Çağlar, 2009; Raüchle \& Schmiz, 2019).

\section{Acknowledgments}

The authors gratefully acknowledge financial support from the Construction, Urbanism, Architecture Plan of the Ministry of Ecology. They wish to thank Mariana Tournon who participated in the research, and Neil
O'Brien for the proofreading. Then they also thank the many key informant and the exiles interviewees.

\section{Conflict of Interests}

The authors declare no conflict of interests.

\section{References}

Arino, J.-M., Moutselos, M., Schönwälder, K., Jacobs, C., Schiller, M., \& Tandé, A. (2018). Why do some cities adopt more diversity policies than others? A study in France and Germany. New York, NY: MacMillan Publishers.

Babels, Bontemps, V., Makaremi, C., \& Mazouz, S. (2018). Entre accueil et rejet: Ce que les villes font aux migrants [Between welcoming and exclusion: What cities make to migrants]. Lyon: Le passager Clandestin-Bibliothèque des frontières.

Bazurli, R. (2019). Local governments and social movements in the 'refugee crisis': Milan and Barcelona as "cities of welcome." South European Society and Politics, 24(3), 343-370.

Béal, V., \& Pinson, G. (2014). When mayors go global: International strategies, urban governance and leadership. International Journal of Urban and Regional Research, 38(1), 302-317.

Bell, D., \& Jayne, M. (2009). Small cities: Towards a research agenda. International Journal of Urban and Regional Research, 33(3), 683-699.

Bernardot, M. (2005). Déplacer et loger les indésirables, sociologie du logement contraint [Displacing and housing the unwanted, sociology of constrained Housing]. Esquisses, Recueil Alexandries, 2. Retrieved from https://www.reseau-terra.eu/article337.html

Berthomière, W., \& Imbert, C. (2019). Quand s'engager ancre et s'ancrer "engage": Les voies plurielles de l'autochtonie au sein des réseaux d'aide aux exilés en Ariège [When commitment anchors and anchoring "engages": The plural paths of Autochtony inside support networks for exiles in Ariège]. L'Espace Politique, 38(2). https://doi.org/10.4000/ espacepolitique.6832

Blanc, M. (2010). The impact of social mix policies in France. Housing Studies, 25(2), 257-272.

Bolt, G., Phillips, D., \& van kempen, R. (2010). Housing policy, (de)segregation and social mixing: An international perspective. Housing Studies, 25(2), 129-135.

Bourgeois, M. (2017). Tris et selections des populations dans le logement social. Une ethnographie comparée de trois villes françaises [Sorting and selecting populations in social housing. A comparative ethnography of three French cities] (Unpublished Doctoral dissertation). Sciences Po, Paris, France.

Caponio, T. (2018). Immigrant integration beyond national policies? Italian cities' participation in European city networks. Journal of Ethnic and Migration Studies, 44(12), 2053-2069. 
Dekker, K., \& van Kempen, R. (2004). Urban governance within the big city policy. Cities, 21(2), 109-117.

Deschamps, C., Laé, J.-F., Overney, L., \& Proth, B. (2017). Parcours de l'exilé: Du refuge à l'installation [Exiles'trajectories: From refuge to settlement]. Paris: PUCA-Plan Urbanisme Construction Architecture.

Downing, J. (2015). European influence on French diversity policy: Lyon's membership of the intercultural cities program. Ethnic and Racial Studies, 38(9), 1557-1572.

Escafré-Dublet, A., \& Lelévrier, C. (2019). Governing diversity without naming it, an analysis of neighbourhood policies in Paris. European urban and Regional Studies, 26(3). https://doi.org/10.1177/ 0969776417750439

Favell, A. (1998). Philosophies of integration. Immigration and the idea of citizenship in France and Britain. Basingstoke: Pagrave MacMillan.

Frigoli, R. (2004). Le demandeur d'asile: Un "exclu" parmi d'autres? La demande d'asile à l'épreuve des logiques de l'assistance [The asylum seeker: one of the "excluded" among others? Asylum application tested by the logic of assistance]. Revue Européenne des Migrations Internationales, 20(2), 153-167.

Furri, F. (2017). Villes-refuge, villes rebelles et néomunicipalisme [Refuge cities, rebel cities and neomunicipalism]. Plein Droit, 115, 3-6.

Gebhardt, D. (2016). When the state takes over: Civic integration programmes and the role of cities in immigrant integration. Journal of Ethnic and Migration Studies, 42(5), 742-758.

Glick Schiller, N., \& Çağlar, A. (2009). Towards a comparative theory of locality in migration studies: Migrant incorporation and city scale. Journal of Ethnic and Migration Studies, 35(2), 177-202.

GIP-HIS. (2018). Bilan 2018 mobilité nationale: Plateforme nationale pour le relogement des réfugiés [Assessment 2018 of national mobility: National platform for the resettlement of refugees] (December 2018 Report). Montreuil: GIP-HIS.

Guiraudon, V. (2010). Les effets de l'européanisation des politiques d'immigration et d'asile [The effects of the Europeanisation of immigration and asylum policies]. Politique européenne, 31, 7-32.

Kobelinsky, C. (2008). "Faire sortir les déboutés." Gestion, contrôle et expulsion dans les centres pour demandeurs d'asile en France ["Getting out the rejected." Management, control and eviction in Asylum seekers shelters in France]. Cultures \& Conflits, 71, 113-130.

Lae, J.-F. (2018). Politique nationale de l'accueil en France: Entre évacuation et décentralisation [National welcoming policy in France: Between eviction and décentralisation]. In Babels (Eds.), Entre accueil et rejet: Ce que les villes font aux migrants [Between welcoming and rejection: What cities make to migrants] (pp. 123-137). Lyon: Le passager ClandestinBibliothèque des frontiers.

Le Courant, S. (2016). Trapped to the local: The effects of immigration detention in France. In R. Furman, D. Epps, \& G. Lamphear (Eds.), Detaining the immmigrant other: Global and transnational issues (pp. 129-139). Oxford: Oxford University Press.

Lévy-Vroelant, C. (2014). Contradictory narratives on French social housing: Looking back and looking forward. Housing Studies, 29(4), 485-500.

Mainet, H. (2011). Les petites villes françaises en quête d'identité. Ambiguïté du positionnement ou image tactiquement combinée? [Small French towns in search of identity. Ambiguity of positioning or tactically combined image?]. Mots, les langages du politique, 3(97), 75-89.

Meier, S. (2018). Being acomodated well, then? Scalar narratives on urban transformation and asylum seekers' integration in mid-sized cities. Urban Planning, 3(4), 129-140.

Pauvros, M. (2014). Les politiques locales d'immigration: Un redéploiement des frontières de l'État (Unpublished Doctoral dissertation). Université Paris 7, France.

Raco, M. (2018). Critical urban cosmopolitism and the governance of diversity in European cities. European Urban and Regional Studies, 25(1), 8-23.

Raüchle, C., \& Schmiz, A. (2019). Migrant economies: Opportunity structures and potential in different city types. Ethnic and Racial Studies, 42(10), 1766-1787.

Rigoni, I. (2018). Logiques institutionnelles et répertoires d'action après Calais. Hétérogénéité des pratiques des acteurs sociaux et politiques depuis le démantèlement du bidonville de Calais [Institutional logics and set-up of action after Calais. Heterogeneous practices of social and political actor after the dismantling of the Calais Jungle]. Sciences et Actions Sociales, 9. Advance online publication. Retrieved from http://www.sas-revue.org/n-conception/51 $n-9 /$ dossiers-n-9/133-logiques-institutionnelles-etrepertoires-d-action-apres-calais-heterogeneitedes-pratiques-des-acteurs-sociaux-et-politiquesdepuis-le-demantelement-du-bidonville-de-calais

Sala-Pala, V. (2013). Discriminations ethniques. Les politiques du logement social en France et au RoyaumeUni [Ethnic discriminations. Social housing policies in France and UK]. Rennes: PUR.

Saunders, D. (2011). Arrival city: How the largest migration in history is reshaping our world. New York, NY: Random House.

Scholten, P., \& Penninx, R. (2016). The multilevel governance of migration and integration. In B. GarcesMascarenas \& R. Penninx (Eds.), Integration processes and policies in Europe: Contexts, levels and actors (pp. 91-108). Rotterdam: IMISCOE.

Simon, P., \& Sala-Pala, V. (2010). "We're not all multiculturalists yet": France swings between hardintegration and soft anti-discrimination. In S. Vertovec \& S. Wessendorf (Eds.), The multiculturalism blacklash: European discourses, policies and practices (pp. 92-110). London: Routledge. 
Valluy, J. (2007). L'accueil étatisé des demandeurs d'asile: De l'enrôlement dans les politiques publiques à l'affaiblissement des mobilisations de soutien aux exilés [State welcoming of asylum seekers: From enrolment in public policies to the weakening of mobilisations in support of the exiles]. Paris: TERRA-Editions.

Vertovec, S. (2007). Super-diversity and its implications.
Ethnic and Racial Studies, 30(6), 1024-1054.

Zapata-Barrero, R., Caponio, T., \& Scholten, P. (2017). Theorizing the 'local turn' in a multi-level governance framework of analysis: a case study in immigrant policies. International Review of Administrative Sciences, 83(2), 241-246.

\section{About the Authors}

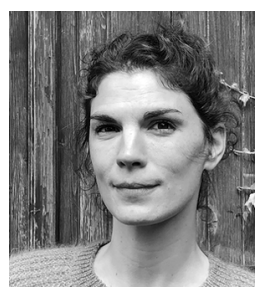

Camille Gardesse is an Urban Sociologist and Associate Professor at the Paris School of Urban Planning (EUP) and member of the research centre Lab'Urba, Université of Paris-Est Créteil. She took part in the Babels Project by conducting a field survey in Paris on the mobilization of inhabitants in support of migrants sleeping in street camps. She then worked on the settlement of asylum seekers and refugees in medium-sized cities, first around the installation of Reception and Orientation Centres then, with Christine Lelévrier, she developed the research referred to in the article.

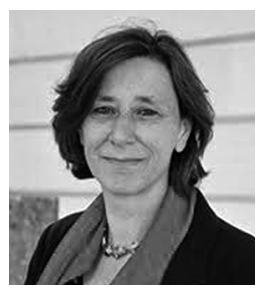

Christine Lelévrier is an Urban Sociologist and Professor at the Paris School of Urban Planning (EUP) and member of the research centre Lab'Urba, Université of Paris-Est Créteil. Her research interests include segregation and ethnic minorities, residential mobility and urban policies in deprived neighbourhoods. Last ten years, she has been carried out research on relocation and social interaction in renewed large social housing estates. From 2013 to 2017, she was part of the European project "Divercities, Governing Urban Diversity," comparing diversity in 13 countries and large cities. Then, she developed research on migrants in medium-sized cities with French and German researchers. 